\title{
Stereotactic Biopsy of Brain
}

National Cancer Institute

\section{Source}

National Cancer Institute. Stereotactic Biopsy of Brain. NCI Thesaurus. Code C51655.

An X-ray procedure using multiple coordinates to precisely determine the location of a tumor or nodule in the brain so as to obtain a tissue sample. 